\title{
Allelopathic potential of the pea seed powder as natural herbicide for controlling weeds infested wheat plants
}

\author{
Kowthar Gad El-Rokiek, Samia Amin Saad El-Din, Mona Adel El-Wakeel (D, Mohammad El-Sayed El-Awadi and \\ Mona Gergis Dawood
}

\begin{abstract}
Background: Allelopathy is an alternative safe strategy for chemical herbicides in controlling weeds. So, two successive greenhouse experiments were conducted to determine the phytotoxicity of pea seed powder on two weeds chard- (broad leaf) and canary grass (grass weed)-infested wheat. Pea seed powder was added to the soil surface at successive rates 20,40,60,80, and $100 \mathrm{~g} /$ pot. The pots were cultivated on time (at sowing application) or 1 week after the addition of the pea seed powder.

Results: The results indicated that the pea seed powder at $100 \mathrm{~g} /$ pot controlled more than $70-80 \%$ of both weeds in comparison to the corresponding controls. On the other hand, the inhibitory effect of the pea seed powder on weeds was accompanied by increases in the growth as well as photosynthetic pigments content and consequently wheat yield especially at $80 \mathrm{~g} / \mathrm{pot}$.

Conclusion: This study suggested that the pea seed powder has allelopathic and phytotoxic effects that controlled investigated weeds in wheat. Analysis of the allelopathic pea seed powder at the applied rates revealed the presence of phenolic compounds and flavonoids. Both allelopathic compounds showed high levels with increasing the pea seed powder rate. The mixing of pea seed powder with the soil surface at $80 \mathrm{~g} /$ pot 1 week before sowing was the most efficient treatment in controlling weeds under investigation that consequently achieved the highest wheat yield.
\end{abstract}

Keywords: Allelopathy, Pea, seed powder, Wheat, Weeds, Phenolic compounds, Flavonoids

\section{Background}

Wheat (Triticum aestivum L.) is one of the most important crops in the world. It is considered as the main source of food in Egypt. Weeds are the most important class of pests that interfere with crop plants through competition resulting in direct loss to quantity and quality of the yield (Khaliq et al. 2011). It was reported that grassy and broad-leaved weeds caused $48-65 \%$ yield loss in wheat (Khan and Haq 2002; El-Rokiek et al. 2014). Recent studies found that allelopathy can be considered as an important mechanism of plant invasions (El-Rokiek et al. 2018). Allelopathic plants release secondary metabolites to the surrounding environment in a phenomenon called allelopathy (Sbai et al. 2016).

* Correspondence: m.elwakeel2000@yahoo.com

Botany Department, National Research Centre, Dokki, Giza, Egypt
These secondary metabolites are called allelochemicals or allelopathic compounds which may be phytotoxic or stimulators to the neighboring plants (Rice 1984). Using allelopathy in weed control is a strategy to overcome the resistance generated from the continuous use of the herbicides (Duke et al. 2001) and minimize environmental pollution (Al-Samarai et al. 2018). In general, many workers controlled weeds using different parts of allelopathic plants (El-Rokiek et al. 2014, 2017, 2018; Ahmed et al. 2018; Al-Samarai et al. 2018). It was documented that some leguminous plants have allelopathic property such as in Pea (Akemo et al. 2000 and Kato-Noguchi 2003), Vicia villosa (Kamo et al. 2006), Mucuna \pruriens (Fujii 2001), Medicago sativa (Xuan et al. 2003), Glycin Max (Huber and abney 1986; Xiao et al. 2006; Yan and yang 2008), Cicer arietinum (Yasmin et al. 1999), 
Trifolium pretense (Qasem 2006) and Vigna unguiculata (Narwal and Haouala 2013). Likewise, Hill et al. 2006 and Hill et al. 2007 reported that the residual extracts of both Vicia villosa and Vigna unguiculata reduced germination as well as radicle growth of Stellaria media, Amaranthus retroflexus, Daucus carota, and Solanum lycopersicum. Poonpaiboonpipattana et al. 2015 studied the allelopathy of dried powders of 12 leguminous plants on germination, shoot and root growth of Echinochloa crus-galli. The authors recorded great suppression especially by Centrosema pascuorum, Clitoria ternatea and Stylosanthes guianensis. The uses of bioherbicides have a dual purpose: the first is to minimize the use of chemical herbicides to reduce environmental pollution. The second is to overcome the resistance of weeds against chemical herbicides.

\section{Object}

To know in what way mixing pea seed powder can participate in controlling weeds (chard and canarygrass) associated wheat plants.

\section{Materials and methods}

Preparation of allelopathic materials

Seeds of pea (Pisum sativum) were obtained from the Agricultural Research Centre, Giza, Egypt. Healthy seeds were ground to fine powder, weighed, and prepared for the experiment.

\section{Experimental procedure}

Two pot experiments were carried out in the last week of November during two successive winter seasons of the years 2016/2017 and 2017/2018 in the greenhouse of the National Research Centre, Dokki, Giza, Egypt. The two experiments were conducted for studying the possibility of controlling weeds, i.e., chard (Beta vulgaris) and canarygrass (Phalaris minor) associated wheat using seeds of pea. Wheat grains cultivar (cv. Misr1) were obtained from the Agricultural Research Centre, Giza, Egypt. The pots $\left(30 \mathrm{~cm}\right.$ in diameter and $\left.0.07 \mathrm{~m}^{2}\right)$ sieved soil (2: $1 \mathrm{v} / \mathrm{v}$ clay and sand). The experiment consisted of 14 treatments in which contain two main equal groups. The first group (at sowing application) that contains five treatments applied by mixing the prepared dried pea seed powder with the soil surface before sowing at the rates of 20,40,60, 80, and $100 \mathrm{~g} /$ pot. Immediately after mixing, 10 wheat grains were sown $2 \mathrm{~cm}$ deep and the pots were infested with a constant number of seeds of chard and canarygrass were mixed thoroughly. Whereas, in the second group (1 week before sowing application) that contains five treatments which were applied by mixing pea seed powder with the soil then allowed for extraction by continuous irrigation for 1 week and then sown with wheat grains and weed seeds as above. The four remaining treatments were unweeded, two control treatments for each group. Thinning of wheat seedlings was done after 2 weeks for each part so that 6 homogeneous seedlings were left per pot. This study was applied as factorial experiments in randomized complete block design with 6 replicates. The normal cultural practices of growing wheat plants were followed especially fertilization and irrigation. Three replicates were collected from each treatment 40 days after sowing (DAS) and at harvest.

\section{Weeds and wheat recorded parameters Weeds growth}

In each season, weed samples were taken from each of the three pots 40 DAS and at harvest (all weed samples in each pot were pulled up). The dry weight of chard and canarygrass was recorded after drying in the electric oven at $60{ }^{\circ} \mathrm{C}$.

\section{Wheat}

\section{Growth and photosynthetic pigment parameters}

- Three plants in each pot were taken for recording plant height, number of leaves, and dry weight ( $\mathrm{g} /$ plant) 40 DAS.

- Determination of photosynthetic pigment contents Chlorophyll a, chlorophyll b, and carotenoids were determined in wheat constant leaf (third leaf from the top) at the vegetative growth (40 DAS) according to Moran 1982.

Yield and yield components At harvest, plant height, spike length, no. of spikes/plant, number of spikelets/ spike, weight of grains/spike, grain yield (g/plant), and 1000 grain weight $(\mathrm{g})$ were determined.

\section{Extraction and estimation of the seed allelochemicals}

Small plastic pots $\left(10 \mathrm{~cm}\right.$ in diameter and $\left.0.008 \mathrm{~m}^{2}\right)$ were filled with the same cultivated experimental soil and each one mixed with the dried pea seed powder at the rate of 2, 4, 6, 8, and $10 \mathrm{~g} /$ pot. Standard volume of tap water was added for each pot. The pots were divided in two parts: the first part was filtered at the time, while the second part was left for 1 week with irrigation with tap water then filtration. The extracts of both parts were collected and the total phenolic as well as total flavonoid contents were determined in the water extract of pea seeds according to Srisawat et al. 2010.

\section{Statistical analysis}

All data were statistically analyzed according to Gomez and Gomez 1984 and the treatment means were compared by using the least significant difference (LSD) at $5 \%$ significant level. 


\section{Results}

\section{Effect of pea seed powder on weeds growth}

Both at sowing and 1 week before sowing mixing treatments of pea seeds with soil surface caused a significant reduction in the growth of chard and canarygrass as indicated by mean values in comparison to the corresponding controls (Table 1). The difference between the two applications was significant (A). Great suppression in the two-weed growth (dry weight) was obtained by different rates of pea seed powder especially in pots contained soil mixed with $100 \mathrm{~g} /$ pot with significant different between the mean values (B). This result was true for at sowing and 1 week before sowing mixing application of pea seed powder. Inhibition in both weed growth was higher with indirect applications. At harvest, the inhibition in chard growth reached 71.4 and $83.6 \%$ at sowing and 1 week before sowing incorporation of pea seed powder in comparison to the corresponding controls. The corresponding results in canarygrass were 80.8 and $82.8 \%$.

\section{Effect of pea seed powder on wheat Growth and photosynthetic pigment parameters}

The results in Table 2 show significant differences between mean values of plant height, number of leaves/ plant as well as dry weight/plant at sowing and 1 week before sowing mixing applications of pea seed powder at 40 DAS. The optimum results were obtained at $80 \mathrm{~g} / \mathrm{pot}$ with at sowing and 1 week before sowing applications as indicated by mean values. In addition, mixing pea seed powder with the soil surface at different rates caused significant increases in all growth characters listed in Table 2 in comparison to the corresponding controls. The maximum increase in the dry weight/plant reached $96 \%$ with at sowing application and $200 \%$ with 1 week before sowing application in comparison to the corresponding controls.

\section{Effect of the pea seed powder photosynthetic pigments contents}

Table 3 reveals significant differences in chlorophyll a and $b$ and carotenoids in fresh leaves of wheat due to at sowing and 1 week before sowing addition of the pea seed powder to the soil as indicated by the mean values. Significant differences were obtained also between different rates $(20-100 \mathrm{~g} / \mathrm{pot})$ as compared to the control as referred by mean values. Maximum significant increases in chlorophyll a recorded in healthy wheat plants followed by pea seed powder treatment at $80 \mathrm{~g} /$ pot. Whereas the highest chlorophyll $b$ and carotenoids values over the corresponding controls were recorded with the treatment at $80 \mathrm{~g} /$ pot of both applications especially at sowing application.

\section{Yield and yield components}

The results in Table 4 reveal a significant difference between the mean values of plant height at sowing and 1 week before sowing applications of the pea seed powder. In addition, the mean values of plant height show a significant increase with increasing rates up to $100 \mathrm{~g} /$ pot. The results also indicated that the difference between at sowing and 1 week before sowing applications of pea seed powder was significant in spike length, number of spikelets/spike. While the number of spikes/plant show non-significant difference. The different rates of the pea seed powder increased significantly spike length, number of spikes/plant, and number of spikelets/spike over their corresponding controls as indicated by mean values.

Table 5 shows differences between the mean values due to mixing of pea at sowing and 1 week before sowing in respect to weight of grains/spike, weight of grains/ plant, and weight of 1000 grains. Mixing the successive rates of the pea seed powder with the soil surface (20$80 \mathrm{~g} / \mathrm{pot}$ ) increased significantly the yield characters listed in Table 5 especially at $80 \mathrm{~g} /$ pot over their corresponding controls as indicated by the mean values. In general, the results referred to that the increase in yield and its components was higher with 1 week before sowing application. The greatest significant increase was obtained in potted soil mixed at sowing and 1 week before sowing applications of $80 \mathrm{~g} /$ pot amounted by $167.5 \%$ and $187.7 \%$ respectively over that recorded in corresponding unweeded pots.

\section{Extraction and estimation of the seed allelochemicals}

As shown in Table 6, analysis of the allelopathic pea seed powder at applied successive rates revealed the presence of phenolic compounds and flavonoids. Both allelopathic compounds showed high levels with increasing the pea seed powder rate. Moreover, the concentrations of phenolic compounds and flavonoids in the soil that remained to be extracted for 1 week were higher than at sowing application.

\section{Discussion}

Allelopathy is a phenomenon which has beneficial or harmful effects of a plant (including microorganisms) on another plant through the release of secondary allelochemical compounds in the environment (Cheng and Cheng 2015). The current study was objected to investigate the allelopathic ability of pea seed powder as an example of leguminous plants for controlling weeds in wheat in the greenhouse experiment. The pea seed powder was applied simultaneously at sowing or left for one week before sowing. The results reveal that the graded increase in the rates of the pea seed powder decreased the growth of both chard- and canary grass-infested wheat plants. Higher rates ( 80 and 100 g/pot) were more 


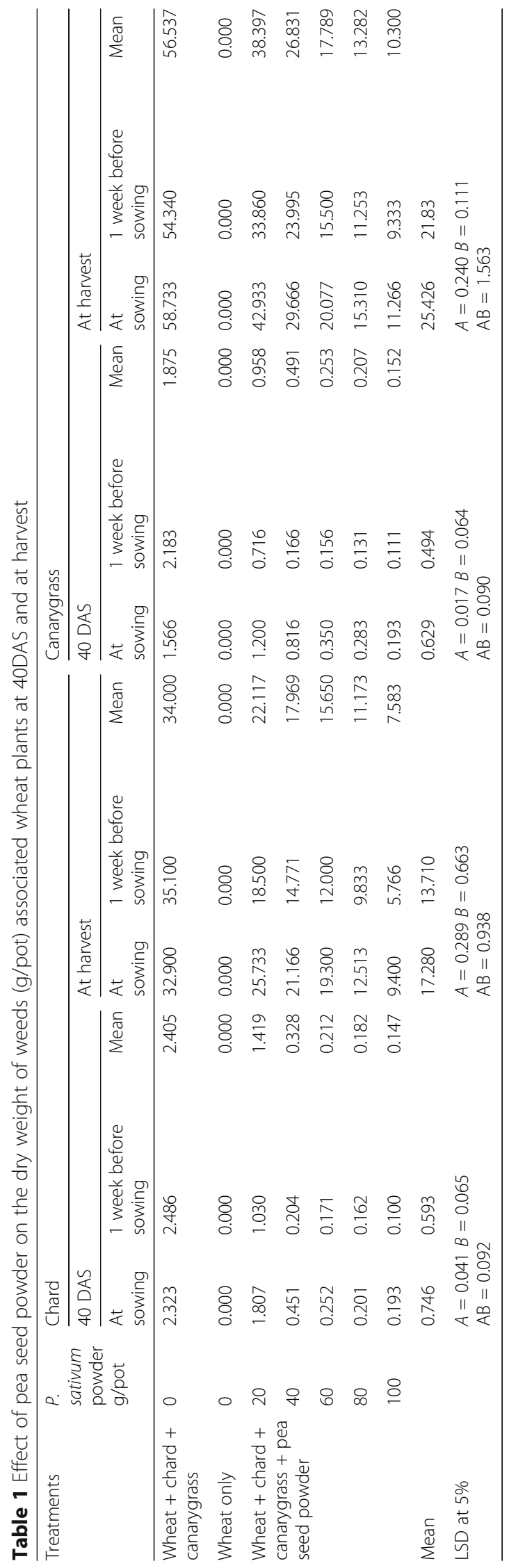


Table 2 Effect of pea seed powder on the growth of wheat plants at 40 DAS

\begin{tabular}{|c|c|c|c|c|c|c|c|c|c|c|}
\hline \multirow[t]{2}{*}{ Treatments } & \multirow{2}{*}{$\begin{array}{l}\text { Pea } \\
\text { seed } \\
\text { powder } \\
\text { g/pot }\end{array}$} & \multicolumn{3}{|c|}{ Plant height $(\mathrm{cm})$} & \multicolumn{3}{|c|}{ Number of leaves/plant } & \multicolumn{3}{|c|}{ Dry weight (g/plant) } \\
\hline & & $\begin{array}{l}\text { At } \\
\text { sowing }\end{array}$ & $\begin{array}{l}1 \text { week before } \\
\text { sowing }\end{array}$ & Mean & $\begin{array}{l}\text { At } \\
\text { sowing }\end{array}$ & $\begin{array}{l}1 \text { week before } \\
\text { sowing }\end{array}$ & Mean & $\begin{array}{l}\text { At } \\
\text { sowing }\end{array}$ & $\begin{array}{l}1 \text { week before } \\
\text { sowing }\end{array}$ & Mean \\
\hline $\begin{array}{l}\text { Wheat + chard + } \\
\text { canarygrass }\end{array}$ & 0 & 31.83 & 32.83 & 32.33 & 4.58 & 4.66 & 4.62 & 1.53 & 1.40 & 1.47 \\
\hline Wheat only & 0 & 48.42 & 53.00 & 50.71 & 6.33 & 6.16 & 6.25 & 3.85 & 4.96 & 4.41 \\
\hline \multirow{5}{*}{$\begin{array}{l}\text { Wheat }+ \text { chard }+ \\
\text { canarygrass }+ \\
\text { pea seed powder }\end{array}$} & 20 & 38.55 & 40.00 & 39.28 & 5.05 & 5.50 & 5.28 & 1.84 & 2.00 & 1.92 \\
\hline & 40 & 40.55 & 45.00 & 42.78 & 5.16 & 5.77 & 5.47 & 2.00 & 3.30 & 2.65 \\
\hline & 60 & 45.33 & 48.15 & 46.74 & 5.83 & 5.83 & 5.83 & 2.18 & 3.85 & 3.02 \\
\hline & 80 & 51.26 & 63.41 & 57.34 & 5.99 & 6.50 & 6.25 & 3.00 & 4.20 & 3.60 \\
\hline & 100 & 45.99 & 54.70 & 50.35 & 5.41 & 5.66 & 5.54 & 2.30 & 3.26 & 2.78 \\
\hline Mean & & 43.13 & 48.15 & & 5.48 & 5.73 & & 2.385 & 3.28 & \\
\hline \multicolumn{2}{|l|}{ LSD at $5 \%$} & \multicolumn{3}{|c|}{$\begin{array}{l}A=0.56 B=1.37 \\
A B=1.93\end{array}$} & \multicolumn{3}{|c|}{$\begin{array}{l}A=0.08 B=0.29 \\
A B=0.41\end{array}$} & \multicolumn{3}{|c|}{$A=0.07 B=0.18 A B=0.26$} \\
\hline
\end{tabular}

phytotoxic in controlling about70-80\% of both weeds especially with sowing application (Table 1). In general, several workers used the allelopathy in controlling weeds (Caamal et al. 2001; Olofsdotter et al. 2002; Kayode and Ayeni 2009; Kato-Noguchi and Salam 2013; El-Rokiek et al. 2014; El-Rokiek et al. 2017)). The allelopathic effect of pea was documented by Akemo et al. 2000. The authors reported that in field experiments, residues and extracts of pea plants suppressed the growth and population of several plant species. Similar results were documented by Kato-Noguchi 2003 and with some other legumes as for example, velvet bean (Mucuna pruriens) (Fujii et al. 1991). In addition, other documented findings supported the present results were reported by Xiao et al. 2006 in soybean.
On the other hand, the adverse effect of the pea seed powder on weed growth-associated wheat plants was accompanied by increases in wheat growth, chlorophyll, and carotenoid contents and consequently yield (Tables 2, 3, 4 and 5). Several workers reported that controlling weeds decreased the interference of weed with crop plants decreasing the competitive ability of associated weeds and consequently increasing the net income in plant growth and yield (Wang et al. 2013; ElRokiek et al. 2014; El-Rokiek et al. 2017).

Plants produce secondary metabolites which usually consist of members from different groups, such as polyphenol, terpenoids (Kato-Noguchi 2003; Wink 2013). Allelochemicals present in the allelopathic plants may be the cause of the weed growth inhibition

Table 3 Effect of pea seed powder on photosynthetic pigment contents $(\mathrm{mg} / \mathrm{g})$ in fresh wheat leaves

\begin{tabular}{|c|c|c|c|c|c|c|c|c|c|c|}
\hline \multirow[t]{2}{*}{ Treatments } & \multirow{2}{*}{$\begin{array}{l}\text { Pea } \\
\text { seed } \\
\text { powder } \\
\text { g/pot }\end{array}$} & \multicolumn{3}{|c|}{ Chlorophyll a } & \multicolumn{3}{|c|}{ Chlorophyll b } & \multicolumn{3}{|c|}{ Carotenoids } \\
\hline & & $\begin{array}{l}\text { At } \\
\text { sowing }\end{array}$ & $\begin{array}{l}1 \text { week before } \\
\text { sowing }\end{array}$ & $\overline{\text { Mean }}$ & $\begin{array}{l}\text { At } \\
\text { sowing }\end{array}$ & $\begin{array}{l}1 \text { week before } \\
\text { sowing }\end{array}$ & $\overline{\text { Mean }}$ & $\begin{array}{l}\text { At } \\
\text { sowing }\end{array}$ & $\begin{array}{l}1 \text { week before } \\
\text { sowing }\end{array}$ & Mean \\
\hline $\begin{array}{l}\text { Wheat }+ \text { chard }+ \\
\text { canarygrass }\end{array}$ & 0 & 0.947 & 1.251 & 1.099 & 0.452 & 0.406 & 0.429 & 0.299 & 0.133 & 0.216 \\
\hline Wheat only & 0 & 1.766 & 1.988 & 1.877 & 0.743 & 0.711 & 0.727 & 0.460 & 0.464 & 0.462 \\
\hline \multirow{5}{*}{$\begin{array}{l}\text { Wheat }+ \text { chard }+ \\
\text { canarygrass }+ \\
\text { pea seed powder }\end{array}$} & 20 & 1.047 & 1.289 & 1.168 & 0.462 & 0.423 & 0.443 & 0.311 & 0.247 & 0.279 \\
\hline & 40 & 1.210 & 1.511 & 1.361 & 0.544 & 0.509 & 0.527 & 0.360 & 0.327 & 0.344 \\
\hline & 60 & 1.326 & 1.591 & 1.459 & 0.604 & 0.525 & 0.565 & 0.379 & 0.342 & 0.361 \\
\hline & 80 & 1.541 & 2.058 & 1.800 & 0.763 & 0.752 & 0.758 & 0.468 & 0.477 & 0.473 \\
\hline & 100 & 1.494 & 1.637 & 1.566 & 0.624 & 0.579 & 0.602 & 0.409 & 0.394 & 0.402 \\
\hline Mean & & 1.333 & 1.617 & & 0.598 & 0.578 & & 0.383 & 0.340 & \\
\hline \multicolumn{2}{|l|}{ LSD at $5 \%$} & \multicolumn{3}{|c|}{$\begin{array}{l}A=0.073 B=0.113 \\
A B=0.160\end{array}$} & \multicolumn{3}{|c|}{$\begin{array}{l}A=0.037 B=0.061 \\
A B=0.086\end{array}$} & \multicolumn{3}{|c|}{$\begin{array}{l}A=0.003 B=0.0 .048 \\
A B=0.068\end{array}$} \\
\hline
\end{tabular}




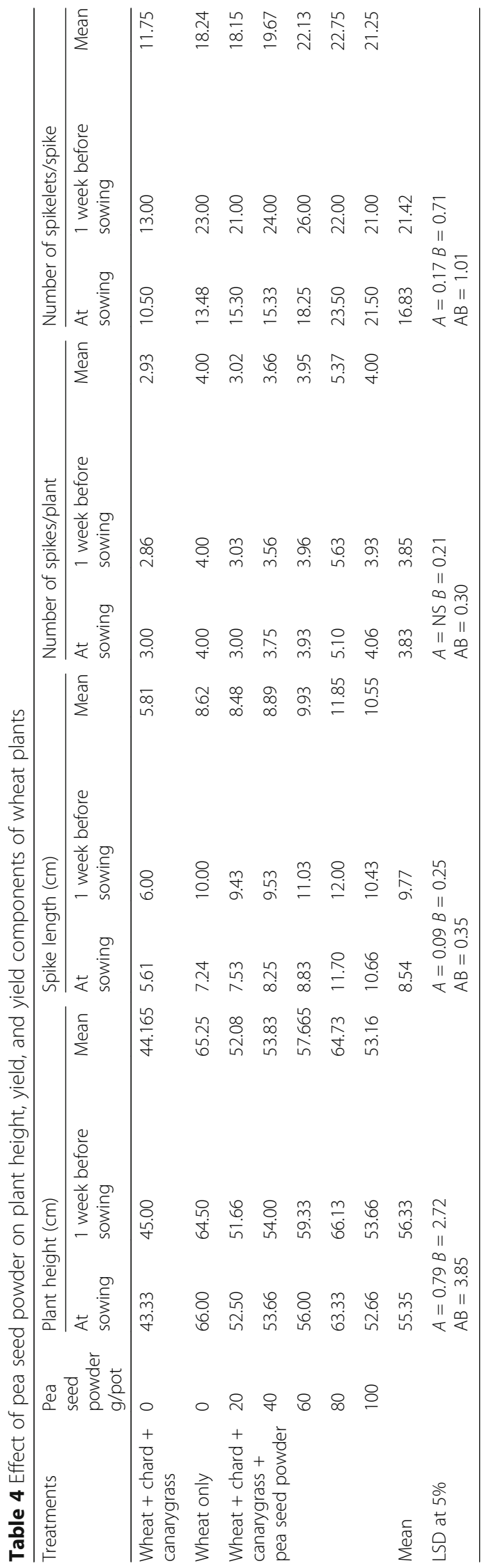


Table 5 Effect of pea seed powder on yield and yield components of wheat plants

\begin{tabular}{|c|c|c|c|c|c|c|c|c|c|c|}
\hline \multirow[t]{2}{*}{ Treatments } & \multirow{2}{*}{$\begin{array}{l}\text { Pea } \\
\text { seed } \\
\text { powder } \\
\text { g/pot }\end{array}$} & \multicolumn{3}{|c|}{ Weight of grain/spike (g) } & \multicolumn{3}{|c|}{ Weight of grain/plant (g) } & \multicolumn{3}{|c|}{ Weight of 1000grains (g) } \\
\hline & & $\begin{array}{l}\text { At } \\
\text { sowing }\end{array}$ & $\begin{array}{l}1 \text { week before } \\
\text { sowing }\end{array}$ & Mean & $\begin{array}{l}\text { At } \\
\text { sowing }\end{array}$ & $\begin{array}{l}1 \text { week before } \\
\text { sowing }\end{array}$ & Mean & $\begin{array}{l}\text { At } \\
\text { sowing }\end{array}$ & $\begin{array}{l}1 \text { week before } \\
\text { sowing }\end{array}$ & Mean \\
\hline $\begin{array}{l}\text { Wheat + chard + } \\
\text { canarygrass }\end{array}$ & 0 & 0.61 & 0.79 & 0.7 & 1.83 & 2.19 & 2.01 & 20.85 & 18.55 & 19.70 \\
\hline Wheat only & 0 & 1.08 & 1.11 & 1.10 & 4.34 & 4.52 & 4.43 & 38.44 & 44.50 & 41.47 \\
\hline \multirow{5}{*}{$\begin{array}{l}\text { Wheat }+ \text { chard }+ \\
\text { canarygrass }+ \\
\text { pea seed powder }\end{array}$} & 20 & 0.74 & 1.79 & 1.27 & 2.43 & 3.69 & 3.06 & 23.61 & 26.51 & 25.06 \\
\hline & 40 & 0.93 & 1.39 & 1.16 & 3.06 & 4.12 & 3.59 & 29.55 & 29.32 & 29.44 \\
\hline & 60 & 0.96 & 1.62 & 1.29 & 3.50 & 4.66 & 4.08 & 34.03 & 34.03 & 34.03 \\
\hline & 80 & 1.72 & 1.63 & 1.68 & 5.06 & 6.30 & 5.68 & 35.81 & 42.15 & 38.98 \\
\hline & 100 & 1.54 & 1.29 & 1.42 & 4.16 & 4.87 & 4.52 & 38.75 & 36.57 & 37.66 \\
\hline Mean & & 1.08 & 1.37 & & 3.48 & 4.33 & & 31.57 & 33.09 & \\
\hline LSD at $5 \%$ & & \multicolumn{3}{|c|}{$\begin{array}{l}A=0.02 B=0.11 \\
A B=0.15\end{array}$} & \multicolumn{3}{|c|}{$\begin{array}{l}A=0.21 B=0.23 \\
A B=0.33\end{array}$} & \multicolumn{3}{|c|}{$\begin{array}{l}A=0.33 B=1.46 \\
A B=2.06\end{array}$} \\
\hline
\end{tabular}

(Cheema et al. 2004; Chou 2010; Chen et al. 2011; ElRokiek et al. 2011; Wang et al. 2013). Herein, the analysis of the pea seed powder extract reveals the presence of flavonoids and phenolic compounds as indicated in Table 6 . The contents increased with the increase in the concentration of the extract especially with one week before sowing application. Thus, confirming our results that increasing the added materials to the soil induced more increase in weed inhibition. In this respect, it was reported that plant phenolics are one of the major chemical groups implicated in allelopathy (Inderjit and Olofsdotter 2002). Putnam 1988 listed flavonoids as allelochemicals that possess actual or potential phytotoxicity which had been isolated from over 30 families of terrestrial and aquatic plants. Abdul-Rahman and Habib 1989, Chung et al. 2000 found caffeic, chlorogenic, isochlorogenic, p-coumaric, p-hydroxybenzoic, and ferulic acids and salicylic acid in Medicago sativa (legume) root exudates and residues and fresh leaves. The authors returned the inhibition in weeds growth to the presence of these materials. Also, El-Rokiek et al. 2011 confirmed these results. In addition, Kato-Noguchi 2003 isolated the putative compound called Pisatin from pea shoots. The author attributed the inhibiting activity of pea on Lepidium sativum L. and Lactuca sativa $\mathrm{L}$. to this putative compound. The explanation of increasing weed inhibition by one week before the sowing application of the pea seed powder may be due that more allelochemical materials extracted in the soil (Table 6).

\section{Conclusions}

Chemical herbicides used to control weeds have toxicological effects on crop plants. Herein, the allelochemicals present in the pea seed powder added to the soil acts as bioherbicides which suppress the growth of both chard and canarygrass associated wheat plants. The mixing of pea seed powder with the soil surface at $80 \mathrm{~g} /$ pot 1 week before sowing was the most efficient treatment in controlling weeds under investigation and gave the highest wheat yield.

Table 6 Total phenolic content and flavonoids in pea seed powder extract when mixed with soil (mg/g)

\begin{tabular}{|c|c|c|c|c|c|c|}
\hline \multirow{2}{*}{$\begin{array}{l}\text { Pea seed } \\
\text { powder } \\
\text { g/pot }\end{array}$} & \multicolumn{3}{|c|}{ Phenol (mg) } & \multicolumn{3}{|c|}{ Flavonoids (mg) } \\
\hline & At sowing & 1 week before sowing & Mean & At sowing & 1 week before sowing & $\overline{\text { Mean }}$ \\
\hline 0 & 0.075 & 0.087 & 0.0810 & 0.006 & 0.012 & 0.009 \\
\hline 20 & 52.360 & 73.590 & 62.975 & 5.660 & 10.593 & 8.127 \\
\hline 40 & 53.130 & 78.270 & 65.700 & 6.231 & 12.463 & 9.347 \\
\hline 60 & 54.890 & 95.370 & 75.130 & 7.945 & 15.891 & 11.918 \\
\hline 80 & 55.000 & 97.515 & 76.257 & 8.983 & 24.096 & 16.539 \\
\hline 100 & 55.880 & 171.270 & 113.575 & 17.292 & 65.016 & 41.154 \\
\hline Mean & 45.222 & 86.017 & & 7.686 & 21.345 & \\
\hline LSD at $5 \%$ & \multicolumn{3}{|c|}{$\begin{array}{l}A=0.510 B=1.930 \\
A B=2.730\end{array}$} & \multicolumn{3}{|c|}{$\begin{array}{l}A=0.131 B=0.156 \\
A B=0.221\end{array}$} \\
\hline
\end{tabular}




\section{Abbreviation}

DAS: Days after sowing

\section{Acknowledgements}

The authors acknowledge the editors for providing us with this opportunity to share our study which investigate the use of allelopathy phenomenon as an alternative to chemical herbicides in controlling weeds. This research was supported and funded by the National Research Centre. Support provided is gratefully acknowledged.

\section{Authors' contributions}

All authors participated in the development and implementation of the research plan. EKG analyzed the data and wrote the manuscript. EMA prepared the manuscript in its final shape. All authors read and approved the final manuscript.

\section{Funding}

This work was supported and funded by the National Research Centre

\section{Availability of data and materials}

All recorded data generated and/or analyzed during the current study are included in this published.

\section{Ethics approval and consent to participate}

Not applicable

\section{Consent for publication}

Not applicable

\section{Competing interests}

The authors declare that they have no competing interests.

Received: 13 November 2019 Accepted: 6 December 2019

Published online: 19 December 2019

\section{References}

Abdul-Rahman AA, Habib SA (1989) Allelopathic Effect of Alfalfa (Medicago sativa L.) on Bladygrass (Imperata cylindrica). J Chem Ecol 15:2289-2300

Ahmed SAA, El-Masry RR, Messiha NK, El-Rokiek KG (2018) Evaluating the allelopathic efficiency of the seed powder of Raphanus sativus $L$. in controlling some weeds associating Phaseolus vulgaris L. Inter J of Environ 7(3):87-94

Akemo MC, Regnier EE, Bennett MA (2000) Weed suppression in spring-sown rye (Secale cereale)-pea (Pisum sativum) cover crop mixes. Weed Technol 14:545-549

Al-Samarai GF, Mahdi WM, Al-Hilali BM (2018) Reducing environmental pollution by chemical herbicides using natural plant derivatives- allelopathy effect. Ann Agric Environ Med 25(3):449-452

Caamal A, Jiménez-Osornio JJ, Torres-Barragán A, Anaya AL (2001) The use of allelopathic legume cover and mulch species for weed control in cropping systems. Agron J 93(1):27-36

Cheema ZA, Khaliq A, Saeed S (2004) Weed control in maize (Zea mays L.) through sorghum. Allelopathy, J Sustain Agric 23(4):73-86

Chen Y, Lin J, Liu SC, Lu PS, Yang DJ (2011) Composition of flavonoids and phenolic acids in Lychee (Litchi Chinensis Sonn.) flower extracts and their antioxidant capacities estimated with human LDL, erythrocyte, and blood models. J of Food Sci 76(5):724-728

Cheng F, Cheng Z (2015) Research progress on the use of plant allelopathy in Agriculture and the Physiological and Ecological Mechanisms of Allelopathy. Front Plant Sci 6(1020):1-16

Chou CH (2010) Role of allelopathy in sustainable agriculture: use of allelochemicals as naturally occurring bio-agrochemicals. Allelopathy J 25: $3-16$

Chung IM, Seigler D, Miller DA, Kyung SH (2000) Autotoxic compounds from fresh alfalfa leaf extracts: identification and biological activity. J. of Chem Ecol 26:315-327

Duke SO, Scheffler BE, Dayan FE, Weston LA, Ota E (2001) Strategies for using transgenes to produce allelopathic crops. Weed Technol 15:826-834

El-Rokiek KG, Ahmed SAA, Messiha NK, Mohamed SA, El-Masry RR (2017) Controlling the Grassy weed Avena fatua associating wheat plants with the seed powder of two brassicaceae plants Brassica rapa and Sinapis alba Middle East J of Agric Res 6(4):1014-1020

El-Rokiek KG, Messiha NK, El-Masry RR, Saad El-Din SA (2011) Evaluating the leaf residues of Eucalyptus globulus and mangifera indica on growth of cynodon dactylon and echinochloacolonum. J Appl Sci Res 7(12):1793-1799

El-Rokiek KG, Saad El-Din SA, El-Wakeel MA, Dawood MG, El-Awad ME (2018) Allelopathic effect of the two medicinal plants Plectranthus amboinicus (Lour. ) and Ocimum basilicum L. on the growth of Pisum sativum L. and associated weeds. Middle East J of Agric Res 7(3):1146-1153

El-Rokiek KG, Saad El-Din SA, Messiha NK, Sharara FAA (2014) Effect of guava leaf residue on broad and narrow leaved weeds associated wheat plants. Inter J Agric Res 9(7):356-363

Fujii Y (2001) Screening and future exploitation of allelopathic plants as alternative herbicides with special reference to hairy vetch. J Crop Prod 4: 257-275

Fujii Y, Shibuya T, Usami Y (1991) Allelopathic effect of Mucuna pruriens on the appearance of weeds. Weed Res in Japan 36:43-49

Gomez KA, Gomez AA (1984) Statistical procedures for agriculture research. In: A Wiley - Inter Science Publication. John Wiley \& Sons, Inc., New York, USA

Hill EC, Ngouajio M, Nair MG (2006) Differential response of weeds and vegetable crops to aqueous extracts of hairy vetch and cowpea. Hort Sci 43:695-700

Hill EC, Ngouajio M, Nair MG (2007) Allelopathic potential of hairy vetch (Vicia villosa) and Cowpea (Vigna unguiculata) methanol and ethyl acetate extracts on weeds and vegetables. Weed Technol 21:437-444

Huber DM, Abney TS (1986) Soybean allelopathy and subsequent cropping. J of Agron and Crop Sci 157:73-78

Inderjit SJ, Olofsdotter M (2002) Joint action of phenolic acid mixtures and its significance in allelopathy research. Physiol Plant 114:422-428

Kamo T, Kato K, Hiradate S, Nakajima E, Fujii Y, Hirota M (2006) Evidence of cyanamide production in hairy vetch Vicia villosa. Nat Prod Res 20(5):429-433

Kato-Noguchi H (2003) Isolation and identification of an allelopathic substance in Pisum sativum. Phytochem 62:1141-1144

Kato-Noguchi H, Salam MA (2013) Allelopathy of Bangladeshi Rice. In: Cheema ZA, Faroog M, Wahid A (eds) Allelopathy Current Trends and Future Applications. Springer Verlag 193-214, New York, USA

Kayode J, Ayeni JM (2009) Allelopathic effects of some crop residues on the germination and growth of maize (Zea mays L.). Pac J Sci Technol 10: 345-349

Khaliq A, Matloob A, Tanveer A, Areeb A, Aslam F, Abbas N (2011) Reduced doses of a sulfonylurea herbicide for weed management in wheat fields of punjab, Pakistan. Chilean J of Agric Res 71(3):424-429

Khan M, Haq M (2002) Wheat crop yield loss assessment due to weeds. Sarhad J of Agric 18:449-453

Moran R (1982) Formulae for determination of chlorophyllous pigments extracted with N,N dimethylformamide. Plant Physiol 69:1371-1381

Narwal SS, Haouala R (2013) Role of Allelopathy in weed management for sustainable Agriculture. ZA Cheema et al. (eds.), Allelopathy, Springer-Verlag Berlin Heidelberg.

Olofsdotter M, Jensen LB, Courtois B (2002) Improving crop competitive ability using allelopathy an example from rice. Plant Breeding 121:1-9

Poonpaiboonpipattana T, Suwunnamek U, Laosinwattana C (2015) Screening on allelopathic potential of 12 leguminous plants on germination and growth of barnyardgrass. J of Agric Technol 11(8):2167-2175

Putnam AR (1988) Allelochemicals from plants as herbicides. Weed Technol 2: $510-518$

Qasem JR (2006) Parasitic weeds and allelopathy, from the hypothesis to the proof. In: Reigosa MJ, Pedrol N, Gonzalez L (eds) Allelopathy, a physiological process with ecological implications. Springer, The Netherlands, pp 565-637

Rice EL (1984) Allelopathy. Academic Press, New York

Sbai H, Saad I, Gheza N, Greca DM, Haouala R (2016) Bioactive compounds isolated from Petroselinum crispum L. leaves using bioguided fractionation. Industrial Crops and Products 89(30):207-214

Srisawat U, Panuto W, Kaendee N, Tanuchit S, Itharat A, Lerdvuthisopon N, Hansakul P (2010) Determination of phenolic compounds, flavonoids, and antioxidant activities in water extracts of Thai red and white rice cultivars. J. of Med. Association of Thailand 93(7):S83-S91

Wang CM, Jhan YL, Yen LS, Su YH, Chang CC, Wu YY, Chang Cl, Tsai SY, Chou CH (2013) The allelochemicals of litchi leaf and its potential as natural herbicide in weed control. Allelopathy J 32(2):157-174

Wink M (2013) Evolution of Secondary Metabolites in Legumes (Fabaceae). South African J of Botany 89:164-175 
Xiao CL, Zheng JH, Zou LY, Sun Y, Zhou YH, Yu JQ (2006) Autotoxic Effects of Root Exudates of Soybean. Allelopathy J 18:121-127

Xuan TD, Tsuzuki E, Matsuo M, Murayama S, Khanh TD (2003) Alfalfa, rice byproducts, and their incorporations for weed control in rice. Weed Biol. Manage 3(2):137-144

Yan F, Yang Z (2008) Allelochemicals in Pre-Cowing Soils of Continuous Soybean Cropping and Their Autointoxication. In: Zeng RS, Mallik AU, Luo SM (eds) Allelopathy in Sustainable Agriculture and Forestry. Springer, New York, pp $271-281$

Yasmin S, Saleem B, Irshad A (1999) Allelopathic effects of aqueous extract of chickpea (Cicer arietinum) and wheat (Triticum aestivum L.) on each other's growth and quality. Inter J of Agric and Biol 1:110-111

\section{Publisher's Note}

Springer Nature remains neutral with regard to jurisdictional claims in published maps and institutional affiliations.

\section{Submit your manuscript to a SpringerOpen ${ }^{\circ}$ journal and benefit from:}

- Convenient online submission

- Rigorous peer review

- Open access: articles freely available online

- High visibility within the field

- Retaining the copyright to your article

Submit your next manuscript at $\boldsymbol{\nabla}$ springeropen.com 